\title{
The Maoist movement and peasant struggle: political ecology approach
}

\author{
Remy Bargout \\ This study was conducted under the supervision of Professor Noella Gray \\ Department of Geography, College of Social \& Applied Human Sciences \\ University of Guelph, Guelph, Ontario, Canada
}

\begin{abstract}
This paper attempts to identify the differences between apolitical perspectives and political ecology approaches to regional socio-environmental issues by delineating the Maoist (Naxal) insurgency in India, using the respective camps of interpretation. A Malthusian view of the issue, within the theory of Eco-Scarcity, is briefly examined. The bulk of this report will pay attention to Environmental Conflict method of describing the rural uprising within the setting of social hierarchies expressed through resource appropriation. The resource categories discussed are agricultural lands, water, forests, and mineral ores.
\end{abstract}

$\mathrm{T}$ he subject of the Maoist or Naxal insurgency in India may initially appear to have a dimensionally static debate surrounding it. However, a political ecology approach in analyzing this issue reveals a diversified topic of complexity. In apolitical terms the Maoist movement is an issue of eco-scarcity. Yet, within the realm of political ecology the movement is a response to greater socioeconomic and environmental pressures, under the environmental conflict thesis. This response is characterized by an armed struggle to give the rural peasantry control over natural resources. The Maoists also struggle to control the discourse surrounding the movement and are engaged in a power struggle with the government. The aim of this paper is to briefly demonstrate an apolitical portrayal of the insurgency, in contrast with the broader views of political ecology in order to fully deconstruct the subject and understand it holistically.

\section{APOLITICAL VIEW: ECO-SCARCITY}

The concept of Eco-scarcity may seem plausible, but in practice does not take other influences into consideration and has continually been proven as fallacious. The argument is based on theorization from Thomas Malthus concerning "the ultimate scarcity of non-human nature and the rapacity of humankind's growing numbers," [1a] beyond the carrying capacity of environmental systems. Situations of eco-scarcity can be perceived as the direst within the context of developing nations such as India, where growth rates and aggregate populations are the highest [1]. When applying the traditional concept of eco-scarcity to the Maoist movement we can simply assume it is the cause of too many people and insufficient resources to sustain human existence; namely land and water. Furthermore, there is increased scarcity of fertile land with which to produce food for the Indian population. This is coupled with a recorded decrease in aggregate agricultural production, imposing food insecurity on Indian households [2]. However, this perspective does not account for underlying socio-economic and environmental explanations that truly give grounds for the rebellion.

\section{Political Ecology View: EnVironmental CONFLICT}

'Poor and landless agricultural labourers' is a typical illustration of one of the demographic majorities in rural Indian. It is these groups for whom the Maoists are fighting. An "age-old association between this lowest ritual status and low economic position" [3a] has allowed for the marginalization of this group. Since 1967, when the Naxalite struggle began in West Bengal, the core motive has been access through force to scarce natural resources, and the benefits that accrue from these resources, for the impoverished Indian peasantry. This includes agricultural lands, groundwater resources, timber, and minerals, which are normally appropriated by the state or the wealthier elite classes [3]. This places the topic well within the framework of the environmental conflict thesis. Environmental conflict can be defined by rises in the scale of discord, between gender, ethnic, or class groups, from resource scarcity due to government, private firms, or social elite extending control over scarce resources [1]. The inequity of resource control can become 'socialized' and 'ecologized' by the affected groups through interventions in the holding and management of resources [1].

Even though Naxalism has persisted for decades, it has surged in recent years and the question as to why this is 


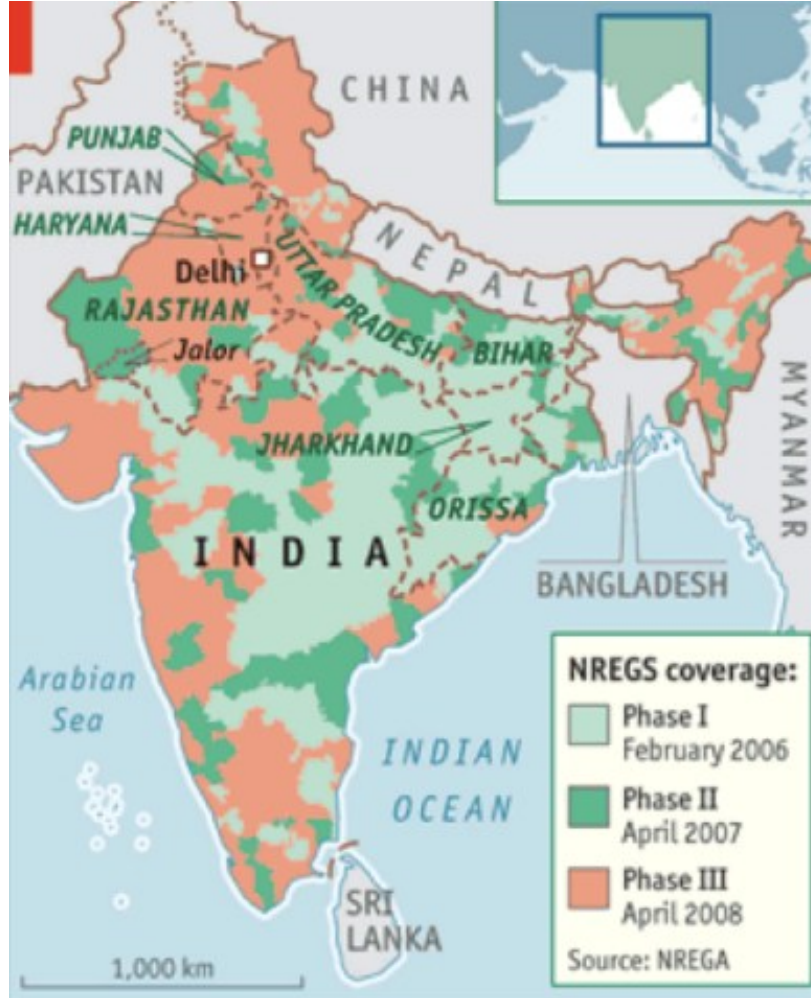

Figure 1. Astill, 2008.

happening is commonly asked. Typically, blame might be put on India's economic liberalization and how it is has created peasant vulnerability to market fluctuations, thus exacerbating economic inequity between the poor and Indian gentry [4]. It is possible that a higher level of awareness to the inequities within the rural land tenure regime, along with the "political mobilization of these grievances" [4a], has allowed the insurgency to grow in recent years more that it has in the earlier half of the century.

There are also cultural variables that perpetuate the maldistribution of land among Indians, mainly through the caste system. The elevation of certain castes to landowning status materialized during India's colonial period when the British East India Company charged them with responsibilities over other Indians, such as collecting land rent. The lowest castes were left to conduct roles in manual labour, and often experience bondage to their landlord in the form of debt. In post-colonial India, the marginalization and impoverishment of the lower castes only intensified, even after the official abolition of the neo-feudal system in 1953 [5]. A dispossessed and discontented mass of poor, rural Indians "found its expression in different Naxalite organizations" [5a].

Although the government has attempted to ameliorate the issue, the solutions have only been palliative and do not address underlying cultural issues or the possible need for widespread, redistributive land reform. Some of these solutions have included ceilings on the amount of owned land and market-based land reform, both of which were

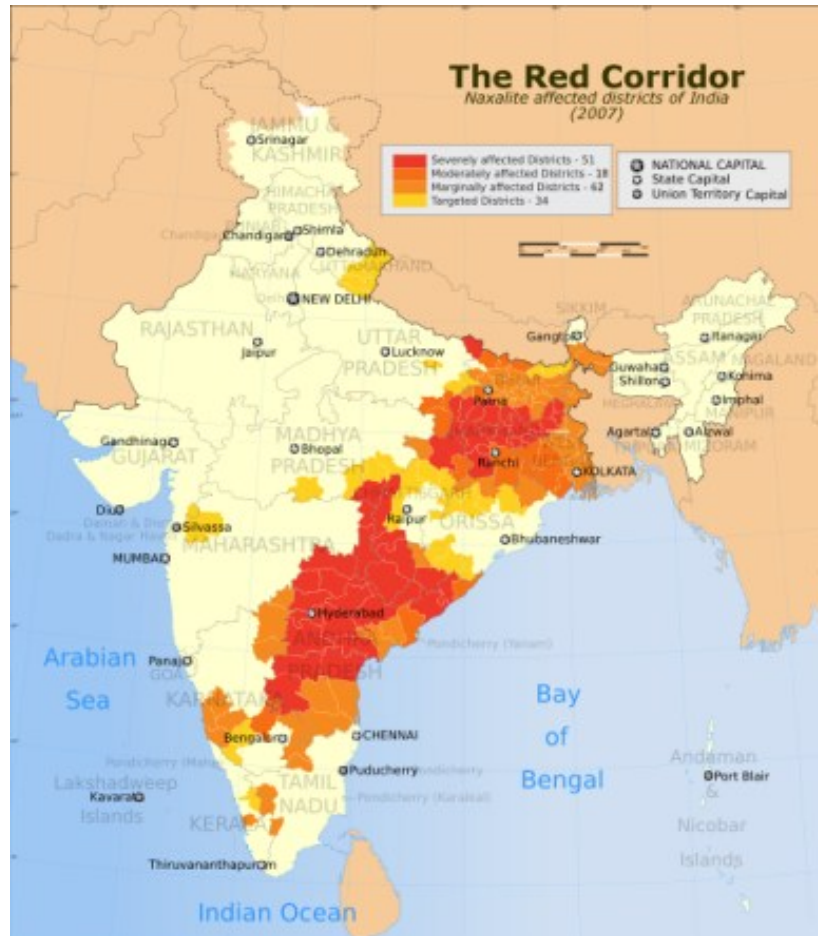

Figure 2. Ganesh, 2009.

flawed and did not have long-term, ubiquitous success. As a result, Maoist popularity has always tended to recuperate, and the current swell of the movement is still largely a topic of access to land for the rural poor [2]. A recent attempt by the Indian government to ease the malaise of the landless agricultural labourers is the National Rural Employment Guarantee Act (NREGA), which guarantees one hundred days of public work to rural households at a daily wage of approximately \$US 1.50 [6]. It was enacted in three phases (Figure 1) with the first phase being executed primarily in Maoist dominated areas (Figure 2). Like solutions before it, the NREGA does not improve a peasant's access to natural resources.

Access to water resources is part and parcel with tenure of agricultural lands. The application of water for agriculture is an essential component under a highly variable rainfall, but proves to be either logistically or economically inaccessible for farmers. This exerts downward pressure on a farmer's situation of poverty. Thanks to traditional canal systems becoming decrepit without adequate maintenance and the Indian government's tendency to damn rivers for hydroelectric projects, farmers face some large obstacles in accessing water for crop irrigation [7]. A product of this is that farmers become reliant on groundwater in the absence of rains. Either electricity or a generator pump is needed to extract the water, and many rural areas do not have electric infrastructure or the money to pay for a generator [7]. In some districts Maoists have been assisting the rural poor in their access to groundwater resources. Such as in the Gaya district in the province of Bihar where members of the 
movement were reported to have been "digging wells, paying for repairs of hand pumps, installing new ones, getting wellto-do farmers to use diesel pumps to create water reservoir for village use, as well as ensuring equitable distribution of water" [8a].

Propriety of forest resources has long been an issue within the movement. Maoists have enforced the right of the peasantry to exercise full control over forest resources, since the 1980's. An example of this is exorbitantly raising the price of timber products [8]. Finally, control over mineral resources has developed as an issue for the Maoists. In this situation the environmental conflict is over the inequitable distribution of resource wealth. Often, the benefits from mining operations accrue to private firms and the government, and the locals receive little of the revenue. In this instance, the issue of land access also involves access to mineral resources. This particular issue of land control interacts with the broader political economy of industrialization to create what Oskarsson [2007] deems a 'resource curse' of tribal and peasant people; specifically in the provinces of Orissa, Andra Pradesh, and Maharashtra [9]. A more recent response from the Maoists to this exploitation was to attack one of India's important iron ore pipelines this past year (2009) to prevent further appropriation of resources by the firm Essar Group [10]. Whether by chance or through intention, seventy percent of India's iron ore resources are currently located in areas affected by the Maoists. This potentially gives the insurgents - and subsequently the peasantry - leverage over an estimated eighty four million tons of iron ore that could be produced annually [10].

Theories on power and knowledge by philosopher Michel Foucault offer us a solid analytical framework within which to place the struggle between the Maoists and the government for control over the discourse of the issue. According to Foucault, power is knowledge and what is understood as truth is the effect of power [1]. So, between the Maoists and the government, power is held and exerted by whoever is able to regulate the ideas and perceptions people have about the movement; by "controlling... the 'public transcript"' [11a]. The subsequent power struggle for the discourse is between the government's security-centric portrayal of the Maoists as terrorists, and the Maoists' selfportrayal as freedom fighters against socio-economic injustices.

The state often paints the Maoist movement in a violent light, highlighting atrocities from the armed conflict in order to evoke emotions within the public [12]. Other pro-state environmental groups have accused the Maoists of actually encroaching on scarce Forest resources as opposed to conserving them [13]. Furthermore, they charged the insurgents with capitalizing on the grievances of the rural poor to simply further themselves politically. In 2006 the prime minister of India considerably alienated the Maoists when he stated that the rebellion posed "the single largest internal security threat" [12a].
However, the Maoists rebut in claiming how the government creates a 'fallacy of danger' towards the movements as an excuse to tighten security, suppress freedom, and infringe upon democratic rights. More specifically, the government does this to further marginalize the rural poor in order to fully exercise embedded autonomy; the state is able to ignore the interests of society's marginal groups and focus on areas concerning economic growth $[14,15]$. The other side to this battle of ideas is the Maoists' attempt to document the movement as a "New Democratic Revolution" [12a] to topple the feudal neo-colonial state through nationwide uprising of citizens. It is a movement that is the result of the landlessness, unemployment, abject poverty, and general exploitation of the peasant majority, in light of a government that has ignored mass dissatisfaction [12]. The movement argues that it is not operating outside the political system, rather they are a symptom of dysfunction within the political system; a "consequence of the failure of the state's development model" [12b].

\section{CONCLUSION}

The concept of eco-scarcity explains the subject of the Maoist armed struggle through the means of an increasing population and scarce amount of land. Despite partial truth of these assumptions, this explanation does not offer a full view of the many variables involved in the issue.

Instead, through the lens of political ecology we can use the environmental conflict thesis as a base to fully breakdown the intricacies of this insurgency. What we discover is a conflict borne out of resource domination by the state, private companies, and the social elite.

Represented by this armed struggle, the poor agricultural labourers make a stake for access to land, groundwater, forests, and mined resources, in an attempt to climb out of rural poverty and combat their own marginalization. Furthermore, the Maoists are engaged in a battle of ideas with the government to control the public discourse, in order to maintain and accumulate ideological power.

The Maoist movement is a topic of intense diversity that must be examined within the context of its many facets in order to gain a full understanding and appreciation of what it is in reality, and what it represents in concept.

\section{ACKNOWLEDGEMENTS}

The author would like express gratitude towards their course supervisor Dr. Noella Gray for her personal assistance in making the course material clear and intriguing to the author, and Dr. Gray's coaching throughout the construction of this paper in the Fall of 2009.

\section{REFERENCES}

1. Robbins, P. 2004. Political Ecology. MA, United States: Blackwell Publishing. 3-15, 41-67. a:7.

2. Bandyopadhyay, D. 2008. Does Land Still Matter? Economic and Political Weekly. 43(10): 37-42. 
3. SinghaRoy, D.K. 2005. Peasant Movements in Contemporary India: Emerging Forms of Domination and Resistance. Economic and Political Weekly. 40(52): 5505-5513. a:5505.

4. Ganguly, S. 2009. Indian in 2008: Domestic Turmoil and External Hopes. Asian Survey. 49(1): 39 - 52. a:43.

5. Kunnath, G.J. 2006. Becoming a Naxalite in Rural Bihar: Class Struggle and its Contradictions. Journal of Peasant Studies. 33(1): 189 - 123. a:93.

6. Astill, J. 2008, April 26. Shoveling for their supper. The Economist (London).

7. Mohanty, N.R. 2006. Chronic Poverty and Social Conflict in Bihar. Indian Institute of Public Administration. New Delhi.

8. Navlakha, G. 2006. Maoists in India. Economic and Political Weekly. 41(22): 2186-2189. a: 2188.

9. Oskarsson, P. 2007. The Resource Curse of the Scheduled Areas: Politics in the Case of the Bauxite Mineral Industry in Tribal Central India. School of Development Studies. Norwich, UK: University of East Anglia.

10. Yardley, Jim. 2009. Maoist Rebels Widen Deadly Reach Across India. The New York Times. Retrieved from http://www.nytimes.com/2009/11/01/world/asia/01maoist.htm 1
11. Bryant, Raymond L. 1997. Beyond the impasse: the power of political ecology in Third World environmental research. Area. 29(1): 5-19. a:12.

12. Giri, S. 2009. Commentary: The Maoist "Problem" and the Democratic Left in India. Journal of Contemporary Asia. 39(3): 463 - 474. a:464 , b:465.

13. Ruckstuhl, Sandra. 2009. Renewable Natural Resources: Practical Lessons for Conflic-Sensitive Development. Sustainable Development Network: The World Bank Group. Washington, DC.

14. Smith, B. 2008. State-Building. In P. Burnell \& V. Randall (Eds.). Politics in the Developing World. 2nd Ed. Oxford: Oxford University Press. 230-348.

15. Chiriyankandath, J. 2008. Colonialism and Post-Colonial Development. In Burnell, P. \& Randall, V. (EDs.), Politics in the Developing World: Second Edition (pp.36-52). Oxford: Oxford University Press.

16. Ganesh, A. 2009. The Red Corridor. Wikimedia Foundation Inc. Retrieved from http://en.wikipedia.org/wiki/File:The_Red_Corridor_ver_1.P NG 